\title{
Distribution of Stem Rust (Puccinia graminis f. sp. tritici) Races in Ethiopia
}

\author{
Endale Hailu ${ }^{1}$, Getaneh Woldaeb ${ }^{1}$, Worku Denbel ${ }^{2}$, Wubishet Alemu ${ }^{3}$, Tekelay Abebe ${ }^{4}$, \\ Agengehu Mekonnen ${ }^{5}$
}

${ }^{1}$ Ambo Plant protection Research centre, Ambo, Ethiopia

${ }^{2}$ Kulumsa Agricultural Research Centre, Asella, Ethiopia

${ }^{3}$ Sinana Agricultural Research Centre, Bale Robe, Ethiopia

${ }^{4}$ Alemata Agricultural Research Centre, Alamata, Ethiopia

${ }^{5}$ Sirenka Agricultural Research Centre, Amhara, Ethiopia

\section{Email address:}

endalehailui@gmail.com (E. Hailu)

\section{To cite this article:}

Endale Hailu, Getaneh Woldaeb, Worku Denbel, Wubishet Alemu, Tekelay Abebe, Agengehu Mekonnen. Distribution of Stem Rust (Puccinia graminis f. sp. tritici) Races in Ethiopia. Plant. Vol. 3, No. 2, 2015, pp. 15-19. doi: 10.11648/j.plant.20150302.11

\begin{abstract}
Wheat is one of the most important cereal crops of Ethiopia. Stem rust caused by Puccinia graminis f. sp. tritici is amongst the biotic factors which can cause up to $100 \%$ yield loss if susceptible cultivar grown and epidemic occurs. The highland of Ethiopia is considered as a hot spot for the development of stem rust diversity. This study was carried out to determine virulence diversity and race distribution of $P$. graminis f. sp. tritici in Ethiopia. Eighty (80) wheat stem rust samples were collected in 2013 cropping season from Oromia, Amhara and Tigray region. Of the samples collected, 66 were analyzed on to the 20 stem rust differential lines. A total of 9 races were identified, which includes TTKSK, TTKTF, TTKTK, JRCQC, TKTTF, TTKSC, TRTTF, SRKSC and RRKSF. Race TTKSK was dominant and widely distributed in the Oromia and Amhara regions with 52\% frequency; it was not isolated in Tigray region. The most virulent and new race, TKTTF which causes localized stem rust epidemic in Bale and Arsi was predominantly distributed in Oromia region with $36.4 \%$ frequency value. Most of the genes possessed by the differentials were ineffective against one or more of the tested isolates. Only stem rust resistance gene 24 was found to confer resistance to all of the races isolated in this study. This gene could be used in combination with other genes through gene pyramiding in breeding for resistance to stem rust in Ethiopia.
\end{abstract}

Keywords: Stem Rust Race, Puccinia graminis f. sp. tritici, Stem Rust Resistance Genes

\section{Introduction}

Bread wheat (Triticum aestivum L. em. Thell) is the world's leading cereal grain where more than one-third of the population of the world uses as a staple food (Curtis, 2002). It is one of the most important cereal crops of Ethiopia (Hailu et al., 1991; Bekele et al., 2000). It ranked fourth in land coverage and total production after tef, maize and sorghum (CSA, 2013). Wheat is produced across a wide range of agro ecological and crop management regime (Belay and Tanners, 1999). The most suitable area for wheat production falls between 1900-2700 m.a.sl (Hailu et al., 1991). Despite the large area under wheat in Ethiopia the national average yield is $2.11 \mathrm{t} / \mathrm{ha}$ (CSA, 2013), which is far below the average of African and world yield productivity. The low productivity is attributed to a number of factors including biotic (diseases, insect pest and weeds) and a biotic (moisture, soil fertility, etc) and adoption of new agricultural technologies (Zegeye et al., 2001). Among these factors, diseases play a significant role in yield reduction.

Wheat is susceptible to many diseases including the highly destructive ones like rusts (Puccinia spp.), Septoria leaf blotches (Septoria tritici), Fusarium head blight (Fusarium graminearum), tan spot (Pyrenophora tritici repentis), smut (Ustilago tritici) and powedery mildew (Erysiphe graminis f.sp.tritici) (Prescott et al. 1986). Over 30 diseases have been reported on wheat in Ethiopia (Bekele 1985). Of these, fungal diseases like rusts ( stem, stripe and leaf rust), Fussarium head blight (FHB), Septoria blotch, Helmenthosporium spp., and tan spot are the dominant ones that were reported over time (Yirgou 1967; Bekele 1985; Badebo 2002; CIMMYT 2005). 
Among these rusts is the most important disease of wheat worldwide, in spite of great progress made in their control in many countries (Saari and Prescot, 1985). Rusts are the major disease of wheat since no other wheat disease could result in greater loss over large area in a given year (Loegering et al., 1967; Amanuel, 1994). Rusts can cause up to 60 percent of yield loss for leaf or stripe (yellow) rust and 100 percent loss for stem rust (Park et al., 2007). The persistence of rust as a significant disease in wheat can be attributed to specific characteristics of the rust fungi. These characteristics include a capacity to produce a large number of spores which can be wind-disseminated over long distances and infect wheat under favorable environmental conditions and the ability to change genetically, thereby producing new races with increased aggressiveness on resistant wheat cultivars.

The high virulence diversity and evolution rate of the pathogen makes a considerable proportion wheat germplasm at risk (Belayneh et al., 2009). According to Leppik (1970), the highland of Ethiopia is considered as a hot spot for the development of stem rust diversity. Furthermore, studies that were carried out in Ethiopia showed that most previously identified races were virulent on most of varieties grown in the country (Belayenh and Embet, 2005; Belayneh et al., 2009) and are among the most virulent in the world (van Ginkel et al., 1989). The past study indicated that race surveys help to generate information regarding the virulence of races and their frequency and distribution patterns across regions and over time (Belayenh et al., 2009). In addition, race survey is important to study evolvement of new races and determine virulence shifts in a population. This information help to detected new race before build inoculums and cause epidemic. Therefore, the currently study was proposed to determine the distribution and dominant virulent races of Puccinia graminis f.sp. tritici in Ethiopia in 2013.

\section{Materials and Methods}

Eighty Stem rust samples were collected from Oromia, Amhara and Tigray regions. Eighty samples were analyzed. Stems of wheat infected with stem rust were cut into small pieces of 5 to $10 \mathrm{~cm}$ in length using scissors and placed in paper bags after the leaf sheath was separated from the stem in order to keep the leaf sheath dry.

Spores were collected in capsule from stem rust infected samples using collector and suspension was prepared by mixing spores with lightweight mineral oil (Soltrol). The spore suspensions were then inoculated using inoculators on seven days old seedlings of the universally rust susceptible variety "Morocco" which does not carry any known stem rust resistance gene to get enough amount of spore to inoculate the stem rust differentials. Greenhouse inoculations were done using the methods and procedures developed by Stakman et al. (1962). The mono-pustule was inoculated and the plants were then moistened with fine droplets of distilled water produced with an atomizer and placed in dew chamber for $18 \mathrm{~h}$ dark at 18 to $22^{\circ} \mathrm{C}$ followed by exposure to light for 3 to $4 \mathrm{~h}$ to provide condition for infection and seedlings were allowed to dry for about $2 \mathrm{~h}$. Then, the seedlings were transferred from the dew chamber to the growth room in the greenhouse where conditions was regulated at $12 \mathrm{~h}$ photoperiod; at temperature of 18 to $25^{\circ} \mathrm{C}$ and relative humidity of 60 to $70 \%$.

Table 1. Nomenclature of Puccinia graminis f. sp. tritici based on 20 differential wheat hosts.

\begin{tabular}{|c|c|c|c|c|c|}
\hline \multirow{5}{*}{$\begin{array}{l}\text { Puccinia graminis f. sp. } \\
\text { tritici -code }\end{array}$} & Set 1 & 5 & 21 & $9 e$ & $7 b$ \\
\hline & Set 2 & 11 & 6 & $8 a$ & $9 g$ \\
\hline & Set 3 & 36 & $9 b$ & 30 & 17 \\
\hline & Set 4 & $9 a$ & 9d & 10 & Tmp \\
\hline & Set 5 & 24 & 31 & 38 & $\mathrm{McN}$ \\
\hline B & & Low & Low & Low & Low \\
\hline C & & Low & Low & Low & High \\
\hline D & & Low & Low & High & Low \\
\hline $\mathrm{F}$ & & Low & Low & High & High \\
\hline G & & Low & High & Low & Low \\
\hline $\mathrm{H}$ & & Low & High & Low & High \\
\hline $\mathrm{J}$ & & Low & High & High & Low \\
\hline K & & Low & High & High & High \\
\hline $\mathrm{L}$ & & High & Low & Low & Low \\
\hline M & & High & Low & Low & High \\
\hline $\mathrm{N}$ & & High & Low & High & Low \\
\hline $\mathrm{P}$ & & High & Low & High & High \\
\hline Q & & High & High & Low & Low \\
\hline $\mathrm{R}$ & & High & High & Low & High \\
\hline $\mathrm{S}$ & & High & High & High & Low \\
\hline $\mathrm{T}$ & & High & High & High & High \\
\hline
\end{tabular}

Source: Roelfs and Martens (1988); Jin et al. (2008); *Low: Infection types $0, ;, 1$, and 2 and combinations of these values. **High: Infection types 3 and 4 and a combination of these values. 
Five seeds each of the twenty wheat stem rust differentials with known resistance genes $(\operatorname{Sr} 5, \operatorname{Sr} 6, \operatorname{Sr} 7 b, \operatorname{Sr} 8 a, \operatorname{Sr} 9 a$, Sr9b, Sr9d, Sr9e, Sr9g, Sr10, Sr11, Sr31, Sr17, Sr21, Sr30, Sr36, Sr38, Sr24, SrTmp, and SrMcN) and one susceptible variety Morocco were grown in $3 \mathrm{~cm}$ diameter pots separately in greenhouse. The single pustule derived spores was suspended in soltrol and inoculated onto seven-day-old seedlings of the differentials using atomizers and/or vacuum pump. After inoculation, the formal procedure was repeated in dew chamber. Upon removal from the dew chamber, plants were placed in separate growth chamber in a greenhouse.

Stem rust infection types were scored after 14 days of inoculations based on Stakman et al. (1962). Zero to four scales was used in which 0-2 stands for low infection where as 3-4 for high infection. To the name the race five letters code nomenclatures were used based on Roelfs and Martens, 1988 and Jin et al. 2008.

\section{Result and Discussions}

\subsection{Stem Rust Race in Ethiopia}

Of 80 stem rust samples collected, 14 did not yield viable isolates at the time of inoculation in the laboratory. Hence, 66 isolates were used for the final race analysis. From 66 isolates studied, 9 races were identified. Fifty seven Puccinia graminis $f$. sp. tritici isolates collected from Oromia region were assigned to 7 races. Similarly, the 8 and 1 isolates collected from Amhara and Tigray region belonged to 2 and 1 race, respectively (Table 5). The highly virulent race Ug99 (TTKSK) was the most abundant and widely distributed race across the country with a frequency of $52 \%$. The second abundant and virulent race was TKTTF (Digelu race) with frequency $36.4 \%$. These two races accounted for almost $88.4 \%$ of the stem rust population. The remaining races composed were TTKTF, TTKTK, JRCQC, TTKSC, TRTTF, SRKSC and RRKSF, which were detected only at a single location each (Table 5). The identification of 9 races from 66 samples is a clear indication of high virulence diversity within the Puccinia graminis f. sp. tritici population in Ethiopia. Admassu and Fekadu (2005) reported that there is high Puccinia graminis f. sp. tritici population variability in Ethiopia.

Of the 57 isolates studied in Oromia region, race TTKSK (Ug99) was dominant with frequency of $47 \%$ followed by race TKTTF (Digelu race) with $42 \%$. In Oromia, the five races TTKTF, TTKTK, JRCQC, TTKSC and TRTTF were the least abundant, each with frequency of less than $5 \%$. In Amhara region, two races, TTKSK (Ug99) and SRKSC were identified in which Ug99 was again the most dominant $(87.5 \%)$ race. Whereas in Tigray reagion, only one race RRKSF was identified from one isolate.

Most of the races were virulent to many of the resistance genes (Table 5). For instance, the differential host carrying the resistance gene 5, 21, 6, 9g, 17, 9a, 9d and McNair were ineffective to all of the races. Similarly, four differential hosts carrying the resistance gene: $9 \mathrm{e}, 11,9 \mathrm{~b}$ and 10 were computable to more than $88.8 \%$ of the races. Gene $\mathrm{Sr} 7 \mathrm{~b}$ and Sr30 were ineffective to seven races where as Sr38, Sr8a and SrTmp were susceptible to six, five and four races, respectively. Sr36 ineffective only to TKTTF race and confirm resistance to the rest eight races. On contrary, Sr24 resistance gene was found to be effective to all races detected in this study and hence can be considered as source of resistance.

Only three of the differential lines carrying resistance genes Sr36, SrTmp and Sr24, were effective against the virulent and dominate race TTKSK (Ug99), whereas Sr11, Sr24 and Sr31 were effective against the virulent race TKTTF.

Table 2. Races of P.graminis f.sp.tritici identified and their virulence spectrum in Amhara, Oromiya and Tigray regions of Ethiopia in 2013.

\begin{tabular}{|c|c|c|c|}
\hline Race & Virulence spectrum (ineffective $\mathrm{Sr}$ resistance genes) & No & $\%$ \\
\hline \multicolumn{4}{|l|}{ Oromia } \\
\hline TTKSK & $5,21,9 \mathrm{e}, 7 \mathrm{~b}, 11,6,8 \mathrm{a}, 9 \mathrm{~g}, 9 \mathrm{~b}, 30,17,9 \mathrm{a}, 9 \mathrm{~d}, 10,31,38, \mathrm{MCN}$ & 27 & 47 \\
\hline TTKTF & $5,21,9 \mathrm{e}, 7 \mathrm{~b}, 11,6,8 \mathrm{a}, 9 \mathrm{~g}, 9 \mathrm{~b}, 30,17,9 \mathrm{a}, 9 \mathrm{~d}, 10, \mathrm{TMP}, 38, \mathrm{MCN}$ & 1 & 2 \\
\hline TTKTK & $5,21,9 \mathrm{e}, 7 \mathrm{~b}, 11,6,8 \mathrm{a}, 9 \mathrm{~g}, 9 \mathrm{~b}, 30,17,9 \mathrm{a}, 9 \mathrm{~d}, 10, \mathrm{TMP}, 31,38, \mathrm{MCN}$ & 1 & 2 \\
\hline JRCQC & 21,9e,11,6,9g,17,9a,9d,MCN & 1 & 2 \\
\hline TTKSC & $5,21,9 \mathrm{e}, 7 \mathrm{~b}, 11,6,8 \mathrm{a}, 9 \mathrm{~g}, 9 \mathrm{~b}, 30,17,9 \mathrm{a}, 9 \mathrm{~d}, 10, \mathrm{MCN}$ & 1 & 2 \\
\hline \multirow[t]{2}{*}{ TRTTF } & $5,21,9 \mathrm{e}, 7 \mathrm{~b}, 11,6,9 \mathrm{~g}, 36,9 \mathrm{~b}, 30,17,9 \mathrm{a}, 9 \mathrm{~d}, 10, \mathrm{TMP}, 38, \mathrm{MCN}$ & 1 & 2 \\
\hline & Total & 57 & 100 \\
\hline \multicolumn{4}{|l|}{ Amahara } \\
\hline TTKSK & $5,21,9 \mathrm{e}, 7 \mathrm{~b}, 11,6,8 \mathrm{a}, 9 \mathrm{~g}, 9 \mathrm{~b}, 30,17,9 \mathrm{a}, 9 \mathrm{~d}, 10,31,38, \mathrm{MCN}$ & 7 & 87.5 \\
\hline SRKSC & $5,21,9 \mathrm{e}, 11,6,9 \mathrm{~g}, 9 \mathrm{~b}, 30,17,9 \mathrm{a}, 9 \mathrm{~d}, 10, \mathrm{MCN}$ & 1 & 12.5 \\
\hline RRKSF & $5,21,7 \mathrm{~b}, 11,6,9 \mathrm{~g}, 9 \mathrm{~b}, 30,17,9 \mathrm{a}, 9 \mathrm{~d}, 10,38, \mathrm{MCN}$ & 1 & 100 \\
\hline G total & & 66 & 100 \\
\hline
\end{tabular}


In general out of nine races identified, the most dominant and virulent races were TTKSK and TKTTF. Most of the genes were ineffective except Sr36, SrTmp and Sr24 against TTKSK race. The discovery of the race Ug99 with Virulence to Sr31 in Uganda in 1999 (Pretorius et al, 2000) represented a real threat to wheat production in the world, including Ethiopia where stem rust epidemics did not occurre since the resistant cultivar 'Enkoy, (Ayele, 2005) lost its resistance in 1993. In Ethiopia Ug99 was first detected in 2003 at six dispersed sites (Singh et al., 2006). In this study, also, this race was widely distributed in the central part of the country. Previous study also indicated that $\mathrm{Ug} 99$ were predominantly distributed in the southern and central parts of the country than in northern west of Ethiopia (Admasu et al., 2010).

Likewise, the second most dominant race TKTTF which is known as Digelu race was virulent on 17 stem rust resistant gene and widely distributed in the central and southern eastern part of the country. This race is for the first time reported in Ethiopia and cause localized stem rust endemics in Bale and Arsi zones of Oromia region in 2013. Stem rust resistance gene in Digelu variety SrTmp gene was broken and most farmers grow Digelu variety were highly affected. The Stem rust resistance gene Tmp became in effective in Ethiopia due to the evolvement of new virulent race TKTTF.

\subsection{Virulence Frequency of P. graminis $f$. sp. tritici Isolates on Stem Rust Resistant Genes}

The Stem rust differential host carrying the resistance gene
21, 6, 17, 9a, 9d and $\mathrm{McN}$ were found to be ineffective to all stem rust races detected with. Similarly, six stem rust differentials carrying resistance genes $\operatorname{Sr} 9 d, \operatorname{Sr} 21, \operatorname{Sr} 6, \operatorname{Sr} 10$, $S r 9 g$, and $S r 9 b$ were found to be ineffective against most of stem rust races detected, with virulence frequencies of 65.6, $78.1,75,81.2,87.5$, and 93.8\%, respectively (Table 5). As a whole, about $75 \%$ of the stem rust resistance genes were ineffective to more than $60 \%$ of the isolates. McNair 701 $(\mathrm{SrMcN})$ was ineffective to $96.9 \%$ of the isolates tested (Table 3).

On the contrary, stem rust resistance gene 24 was effective against all races detected. Of the 20 stem rust resistance genes, the differential hosts carrying $\operatorname{SrTmp}, \operatorname{Sr} 31$, and $\operatorname{Sr} 17$ were resistant to $87.5,75.0$, and $78.1 \%$ of the isolates tested, respectively. Gene $\operatorname{Sr} 38$ was effective against $62.5 \%$ of the isolates analyzed followed by $\mathrm{Sr} 36$ which was effective against 59.4\% (Table 3).

Stem rust resistance gene 24 was effective against all of the isolates tested in Ethiopia. Admassu et.al (2010) also indicated that no virulent race was detected against $\mathrm{Sr} 24$ gene in Ethiopia. Use of this gene for breeding in Ethiopia is pertinent (Teklay et.al, 2012). In Ethiopia, stem and yellow rust severely occur every year. Farmers use chemical fungicides to protect there farm from rusts. Use of the chemical fungicides is not economical and unaffordable for small scale farmers. So, continues supply of resistance varieties is needed to avoid wheat rust epidemics in the country.

Table 3. Virulence frequency of P. graminis $f$. sp. tritici isolates (32 isolates) on 20 Stem rust resistance genes.

\begin{tabular}{llll}
\hline Stem rust resistance gene (Sr gene ) & Virulence frequency (\%) & Stem rust resistance gene (Sr gene) & Virulence frequency (\%) \\
\hline 5 & 96.97 & 30 & 98.5 \\
21 & 100 & 17 & 100 \\
$9 e$ & 98.5 & $9 a$ & 100 \\
$7 b$ & 96.97 & $9 d$ & 100 \\
11 & 63.64 & 10 & 98.5 \\
6 & 100 & $T m p$ & 40.91 \\
$8 a$ & 93.94 & 24 & 0 \\
$9 g$ & 98.5 & 31 & 54.55 \\
36 & 62.12 & 38 & 95.5 \\
$9 b$ & 98.5 & $M c N$ & 100 \\
\hline
\end{tabular}

\section{Acknowledgment}

We would like to offer a great thanks to wheat rust research team of Ambo plant protection research Center for their valuable encouragement and technical support during the whole period of the study. Without the support of some individuals and institutions the successful completion of this experiment would have not been realized. Durable Rust Resistance in Wheat (DRRW) project and International maize and wheat improvement center (CIMMYT) is duly acknowledged for fully funding this work.

\section{References}

[1] Admassu B, Fekadu E, 2005. Physiological races and virulence diversity of Puccinia graminis f.sp. tritici on wheat in Ethiopi. Phytopathologia Mediterranea 44,313-318

[2] Admassu B. 2010. Genetic and virulence diversity of Puccinia graminis $\mathrm{f}$. sp. tritici population in Ethiopia and stem rust resistance genes in wheat. Gottingen, Germany: Gottingen University, PHD thesis. 
[3] Badebo A. 2002. Breeding Bread Wheat with Multiple Disease resistance and high the yielding for the Ethiopian highlands: broadening Genetic basis of yellow rust and tan spot resistance. Gottingen, Germany: Gottingen University, PHD thesis.

[4] Bekele, Verkuiji H. MWangi W. and Tanner D. 2000. Adoption of improved wheat techenologies in Adaba and Dodola woredas of the Bale high lands, Ethiopia, Mexico, D.F. CIMMYT and EARO

[5] Bekele E.1985. A review of research on diseases of berley, tef and wheat in Ethiopia. In: Tsedeke Abate (ed.), A review of crop protection research in Ethiopia. Institute of Agricultural Research (IAR), Ethiopia, pp.79-107.

[6] CIMMYT. 2005. Sounding the alarm on global stem rust: an assessment of race Ug99 in Kenya and Ethiopia and potential for impact in neighboring countries and beyond. Mexico city. Mexico

[7] CSA (central statistics Authority). 2013. Report on area and crop production forecast for major grain crops. Addis Ababa, Ethiopia: statistical bulletin

[8] Hailu G., Tanner, DG. And Mengistu, H. (eds). Wheat research in Ethiopia: A Historical perspective, IARI and CIMMYT, Addis Ababa. PP.392

[9] Jin Y, Szabo U, Pretorius ZA, Singh RP, Ward R, Fetch T, 2008. Detection of virulence to resistance gene $\operatorname{Sr} 24$ within race TTKS of Puceinia graminis f. sp. tritici. Plant Dis. 92: 923-926

[10] Prescott JM, Burnett PA, LeSaari EE, Ranson J, Bowman J, Milliano W de, Singh RP and Beke G. 1986. Wheat diseases and pests: a guide for field identification. CIMMYT, Mixico city. DF. Mexico.135pp

[11] Pretorius ZA, Singh RP, Wagoire WW, Payne TS, 200, Detection of virulence to wheat stem rust resistance gene $\mathrm{Sr} 31$ in Puccinia graminis f. sp. tritici in Uganda. Phytopathology 84, 526-533.
[12] Peterson RF, Campbell AB, Hannah A (1948) A diagrammatic scale for estimating rust intensity on leaves and stems of cereals. Canadaian Journal Research 26: 496-500.

[13] Roelfs AP, Martens JW, 1988. An international system of nomenclature for $P$. graminis f. sp. tritici. Phytopatholog. 78: 526-533.

[14] Stakman EC, Stewart DM, Loegering WQ, 1962. Identification of physiologic races of Puccinia graminis var. tritici.' USDA ARS, E716. United States Government Printing Office: Washington, DC, pp 5-50.

[15] Teklay A, Woubit D. Getanh W. 2013. Physiological races and virulence diversity of Puccinia graminis pers. f. sp. Tritici eriks. \& e. Henn. On wheat in Tigray region of Ethiopia. ESci J. Plant Pathol. 02 (01) 2013. 01-07

[16] Teklay A, Getaneh W, Woubit D, 2012. Analysis of pathogen virulence of wheat stem rust and cultivar reaction to virulent races in Tigray, Ethiopia. African Journal of Plant Science Vol. 6(9): 244-250.

[17] van Ginkel M, Getinet G, Tesfaye T (1989). Stripe, stem and leaf rust races in major wheat producing areas in Ethiopia. IAR Newslett. Agric. Res., 3: 6-8.

[18] Yirgu D. 1967. Plant diseases of economic importance in Ethiopia. Haile Selassie I university, college of Agriculture, Experimental station bulletin no.50, Addis Ababa, Ethiopia.30pp

[19] Zegeye T. Taye G, Tanner D, Verkuijl H, Agidie A and Mwangi W. 2001. Adoption of improved bread wheat varieties and inorganic fertilizer by small-scale farmers in yelmana Densa and Farta districts of North western Ethiopia. EARO and CIMMYT. Mexico city, Mexico. 